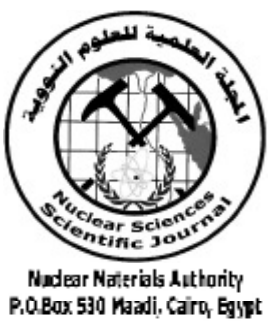

ISSN 2314-5609

Nuclear Sciences Scientific Journal

vol. 4, p $47-59$

2015

\title{
CONTRIBUTIONS TO THE GEOLOGY AND MINERALOGY OF WADI RAS ABDA AREA,NORTH EASTERN DESERT, EGYPT
}

\author{
AHMED F. EL HADARY; ASHRAF E. SOLIMAN and ALI A. OMRAN \\ Nuclear Materials Authority, P.O. Box 530, El-Maadi, Cairo, Egypt
}

\begin{abstract}
Wadi Ras Abda has length of about $10 \mathrm{~km}$ and width reaching to $50 \mathrm{~m}$, and represents the main part of the drainage pattern of the studied area that bears the same name. The drainage patterns of the studied area are generally dendritic and angular patterns to indicate that, the area has been structurally controlled. The dendritic drainage patterns are predominating at the northern parts where fractures, joints, and faults are affected. The angular pattern type occurs often at the southern parts owing sharp intersections of main stream and its tributaries.

Wadi Ras Abda area is dominated by basement rocks encompassing older granitoids, younger gabbros and younger granites as well as several types of post granitic dikes. The studied area is affected by two right-lateral strike-slip faults of NE and NW trends and is influenced by a large graben with $3.2 \mathrm{~km}$ wide and extends for $10.4 \mathrm{~km}$ in the NW-SE direction. The graben was formed through the interaction of the NWoriented right-lateral-slip faults of conjugated dip directions due NE and SW. Mineralogical investigation of three shear zone samples and seven stream sediments samples revealed the presence of several important heavy minerals. These minerals include magnetite, hematite, ilminite, garnet, zircon, sphene (titanite), columbite, samarskite, chromite and platinum.
\end{abstract}

\section{INTRODUCTION}

Ras Abda area is located at about $10 \mathrm{~km}$ south west of Safaga City, at the beginning of wadi Ras Al Barud. It lies between latitudes $26^{\circ} 42^{\prime}$ and $26^{\circ} 46^{\prime} \mathrm{N}$ and longitudes $33^{\circ} 45^{\prime}$ and $33^{\circ} 48^{\prime} \mathrm{E}$. The area is characterized by its rugged topography and high relief. It is intersected by wadi Ras Abda and wadi Abu Hadidah and moreover it is limited to the north and to the south by wadi Ras El Barod and wadi Um Taghir respectively. Wadi Ras Abda run through the middle part of the area and extended to about $10 \mathrm{~km}$ in the ENE direction. Wadi Abu Hadidah extends in the northwestern part. The exposed rock units in the area comprise older granitoids, younger gabbros and younger granites as well as several types of post granite dikes (Fig. 1).

The granitic rocks constitute about $60 \%$ of the total basement of the Nubian Shield in Egypt (Stern and Hedge, 1985). They include two main types:

-The older (Shaitian) covers about $26.7 \%$ of the basement in the Eastern Desert (Stern 1979). They occur as sheared, xenolithic huge masses composed of diorite, granodiorite and tonalite (Akaad and Mustafa, 1963 and El Ramly, 1972) and formed at 880 to 930 m.y. (Hashad, 1980). The older granites are synorogenic (El Shazly, 1964), and calc-alkaline mesozonal granites (Stern et al., 1984) with dominant grey and white colors. Hussein et al., (1982), classified them into GI-type (sub- 


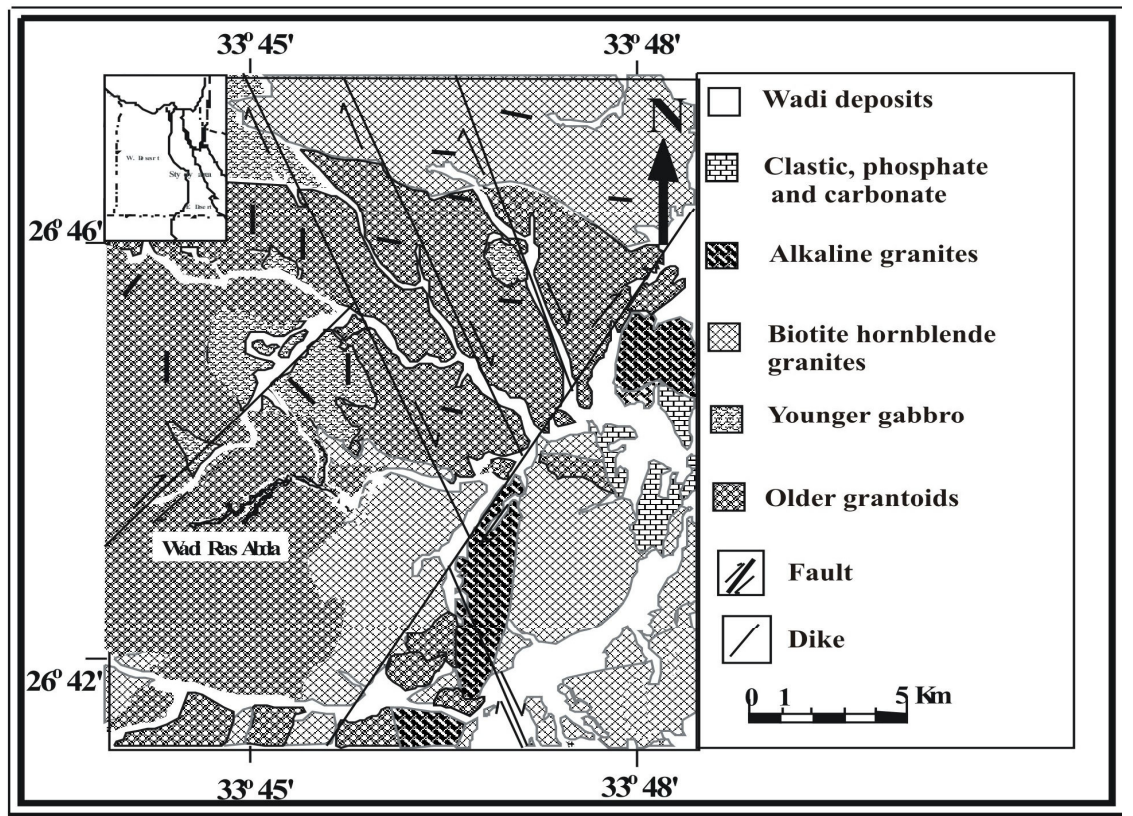

Fig. 1: Geological map of Wadi Ras Abda area, After EGSMA,1987

duction-related) and GII-type (suture-related). El-Gaby et al., (1990) described them as $\mathrm{G} \alpha$ granites.

-The younger granites constitute about $16.2 \%$ of the basement in the Eastern Desert (Stern, 1979) and concentrated in its northern part. They form small rounded to ovoid masses of magmatic origin with sharp intrusive contacts (El Ramly, 1972) and their ages range between 594 and 568m.y. (Hashad, 1980). These granites are pink to red, late-orogenic (El Shazly, 1964) or late to post tectonic (El Ramly, 1972), epizonal granites (Stern et al., 1984) and alkaline to peralkaline intraplate anorogenic granites (GIII-granites), according to Hussein et al., 1982. Noweir et al., (1990) considered the younger granites of Egypt as transitional phases from calcalkaline, I-type magmatism to normal alkaline and alkaline A-type granites. This group comprises granodiorites, syeno-and monzogranites, alkali feldspar granites, peralkaline granites and syenites.

The present study concerned with the geo- logical, petrological and mineralogical features of these rocks through studying of 7 samples of wadi Ras Abda deposits and 3 samples representing the younger granite rocks exposed along a NW shear zone.

\section{GEOLOGIC SETTING}

The area under consideration is occupied by igneous rocks belonging to late Proterozoic units. The constructed geologic map on a scale 1: 40000 of Wadi Ras Abda area (Fig.1), shows the distribution of the various rock types and their mutual field relations and contacts. The exposed rocks namely according to the Geological survey of Egypt in 1987 as follows:

\section{Older Granitoids (Gray Granite)}

In the studied area, the older granitoids represent the dominant rock unit. Which cover about $60 \%$ of the total mapped area (Fig. 1). They form large masses of moderate relief extending as elongated belt to NW direction.

The older granitoids are directly intruded 
by the younger granites and the younger gabbros by sharp intrusive contacts (Figs. 2 \& 3) along wadi Ras Abda, wadi Abu Hadidah and south of wadi Ras Al Barud. Occasionally, the older granitoids show a common presence of pegmatite pockets as well as potash feldspars and quartz veins. On the other hand, they are dissected by some basic and acidic dykes with different thickness and attitudes.

Generally, the older granitoids show a marked variation in composition ranging from quartz diorite through tonalite to granodiorite. They show variation in color from dark to dark pink or whitish pink where most of fractures and joints are stained with iron oxides particularly along the shear zone. The rocks are coarse-grained, highly sheared, and jointed. They are characterized by development of some cavernous structure, exfoliation, and gneissos structure especially along their contacts and peripheries. They are also

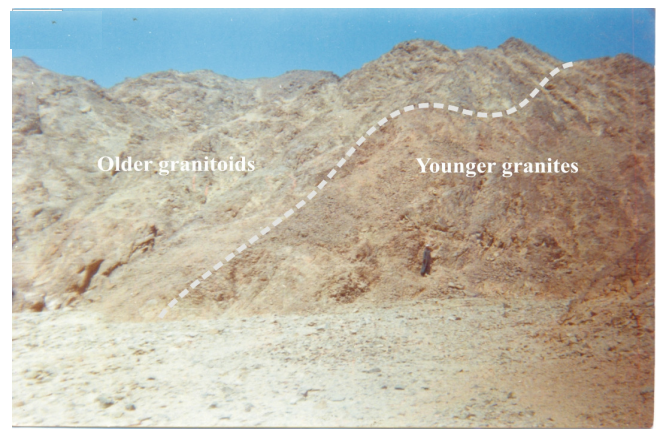

Fig.2:Younger granites intruding the older Granitoids. Looking SW.

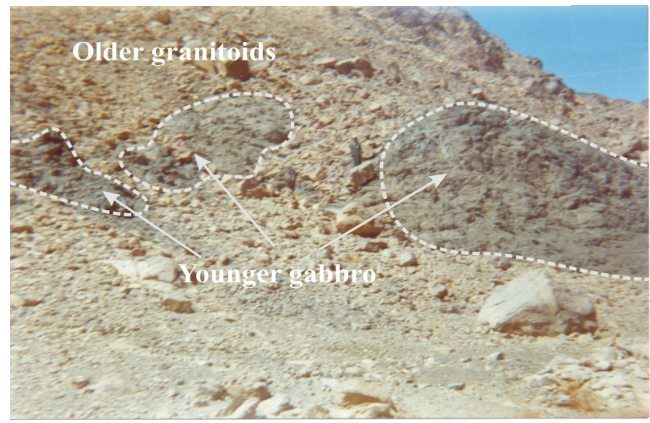

Fig.3: Older granitoids intruded with younger gabbro. Looking S. traversed by some NE and NW wadis with narrow to $963 .^{*}$ moderately width, very sinuous and structurally controls.

\section{Younger Gabbro}

The younger gabbro is mainly represented by pyroxene olivine gabbro. It is hard, compact and medium-grained black colored rock. It occurs as isolated mass occupy about $10 \%$ of the total mapped area (Fig. 1). The mass is occupying the northern part of wadi $\mathrm{Abu}$ Hadieda directly to the south of wadi Ras Al Barud. It is characterized by low to moderate topography and shows bouldery appearance and spheroidal blocks traversed by pegmatite veins and dike swarms. The younger gabbro intrudes the older granitoids, sending several apophyses into them (Fig. 3). On the other hand, the younger gabbro is intruded by the younger granites which carrying them as roof pendants (Fig. 4). The younger gabbro is crossed by wadi Abu Hadida trending NE, that is affected by the NE right lateral strike slip faults in turn. This fault affected the NW right lateral strike slip fault, to suggest that NE faults are younger than the NW ones.

\section{Younger Granites}

These granites were emplaced during the post tectonic episode in Egypt, contemporaneous with the Pan-African tectonic thermal events. Their age ranges from 620 to $530 \mathrm{Ma}$., (El-Manharawy, 1977; Hashad, 1980 and Rogers and Greenberg, 1983).

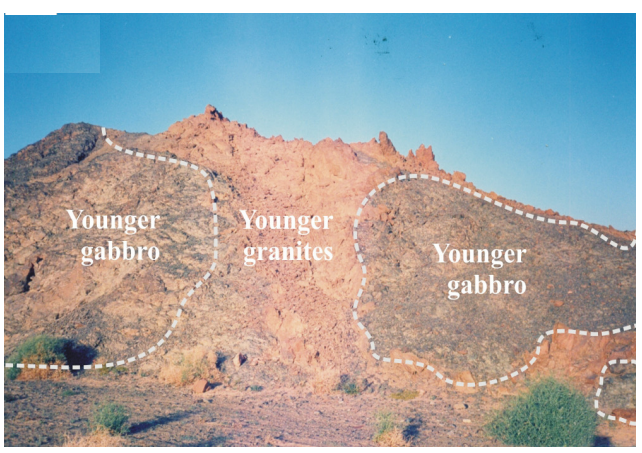

Fig.4:Younger granites intruding and carrying the younger gabbro. Looking NNW. 
The younger granites represent the highest mountainous outcrops, as they are hard and resistant to weathering and erosion. They comprise biotite-hornblende granite and alkaline granites (Fig.1)

The younger granites occupy the southeastern part of the studied area intruding the older granitoids (Fig. 2), and younger gabbro to the west, north, and northwest respectively. The contact area is relatively represented by finer size forming chilled margins, and highly crammed with numerous xenoliths of older granitoids and younger gabbro with different shapes and sizes. Generally, the younger granites send several small offshoots of different sizes and shapes into the older rocks (Fig. 4). They are massive unfoliated rocks, but they, sometimes show slight foliation along the peripheries of plutons. Along the shear zone several mineralized spots and lenses in addition to unzoned pegmatite bodies and pockets are noticed in the younger granites (Fig. 5).

On the other hand, the rocks show various degrees of colors including red, pink, reddish pink, whitish pink, greyish pink and faint yellowish pink colors. Generally, Ras Abda younger granites are more homogeneous in the mineralogical composition. They are usually equigranular medium to coarse-grained rocks.

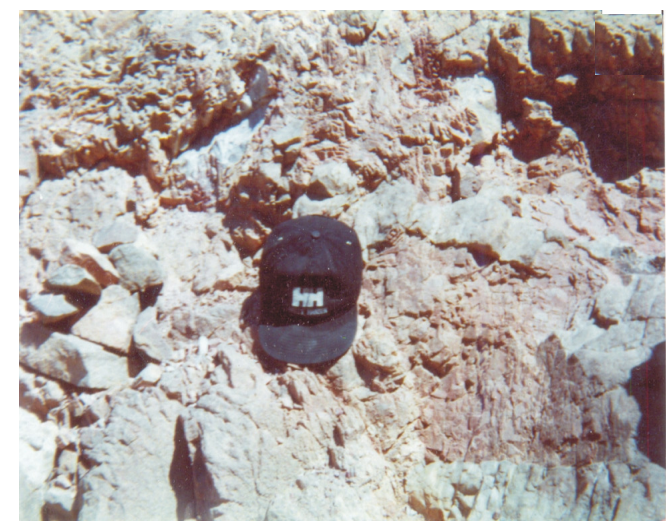

Fig.5: Unzoned pegmatite pocket in younger granites. Looking $\mathrm{E}$.

\section{Dikes}

The rocks of the area under investigation are intersected with numerous dikes ranging from acidic to basic in composition. They are emplaced along regional fractures of NorthSouth, NW-SE, East-West and NE-SW trends. The acidic dikes have usually the greatest length may exceed $2 \mathrm{~km}$; with widths varying from 0.5 to $5 \mathrm{~m}$. These dikes are mainly rhyolites, and fewer microgranite dikes. The basic-intermediate dikes are usually more in number and limited in size compared to the acidic ones, reaching to $2 \mathrm{~km}$ in length and $1 \mathrm{~m}$ in width. These dikes have E-W, and NWSE trends, and concentrated in the western part of the area (Fig.1). They are mainly basaltic composition and cut all rocks cropping out in the area. A huge and long microgabbroic dike, does not extend to other rocks and is not weathered extending in the north-northwest direction is also noticed.

\section{STRUCTURE}

\section{Faults}

Faults represent the main structural features in the study area. Slickensides and grooves are commonly associated with brittle faulting. These kinematic indicators indicate the direction and sense of maximum resolved shear stress in that plane (Carey and Brunier, 1974). Slickensides are often composed of fibrous chlorite crystals, epidote, calcite and quartz that stretch from one side of the fault plane to the other.

The NE-SW trends and NW-SE are rightlateral strike-slip faults (Fig. 1). These faults dislocate the intrusive rocks. Fortunately, the rock exposures provided criteria to evaluate the activity along these faults in chronological order. The NW-SE-trending faults are the oldest fracture planes, followed by the NE-SW orientations. The NE-SW-trending faults dislocate the older oriented faults.

Some faults have a dip-slip component as extension regime defined by slickensides. This 
slip is represented by local normal faults. Field observations indicate that normal faults are mainly concentrated in the younger granites. Vertical slickensides were measured along many fault planes where the pitch angles range between $50^{\circ}$ and $85^{\circ}$; other intersecting feature is the older slickenside lineations.

It is clear that the NE-SW faults represent the normal type, where their movements are observed through vertical or nearly vertical slickensides. Some faults had been effected by hydrothermal processes as episyenitization, silicification and and ferrugination especially at W. Ras Abda. High radioactive anomalous spots, mineralization and the pegmatite pockets are confined to shear zones along these faults.

Many authors realized that strike-slip faulting may generate large and complex basins (e.g. Sengör et al., 1985, in, Silvester, 1988) between curved or releasing overstepped fault segments, depressions develop as sharp, rhomb-shaped basins (Crowell, 1974, Garfunkel, 1981 and Silvester, 1988) or as lazy S- or Z-shaped basins (Schubert, 1984, Mann et al., 1983, and Silvester, 1988) due to local crustal extension. The basins range in size from small sag ponds along a strike-slip fault to rhombshaped basins up to $500 \mathrm{~km}$ long and $100 \mathrm{~km}$ wide.
The area was affected by large graben situated at the central part of the area (Fig. 1). It extends about $10.4 \mathrm{~km}$ to $\mathrm{NW}$ with about $3.2 \mathrm{~km}$ width. It was formed through the interaction of the NW right-lateral-slip faults of conjugated dip directions due NE and SW. The trough of this graben is formed by the younger gabbros, and younger granite. The shoulders are formed by older granitoides and crossed by NE dextral-slip fault.

\section{Drainage Pattern}

Wadi Ras Abda has length of about $10 \mathrm{~km}$ with up to $50 \mathrm{~m}$ width. This wadi is surrounded essentially by older granitoids highly intruded with younger granite offshoots and covered by stream sediments produced from the country rocks and the other wadis through the drainage pattern. This wadi is characterized by the presence of surface gravels, coarse, medium, and fine sand grains, light in colour, with some lenses of black sediments.

The drainage pattern of the study area is generally dendritic and angular pattern (Fig.6). Dendritic pattern is characterized by irregular branching in all directions like the limbs of a tree. It mainly develops in massive crystalline rocks as in the northern part where fracture, joints, and faults. Angular pattern type is

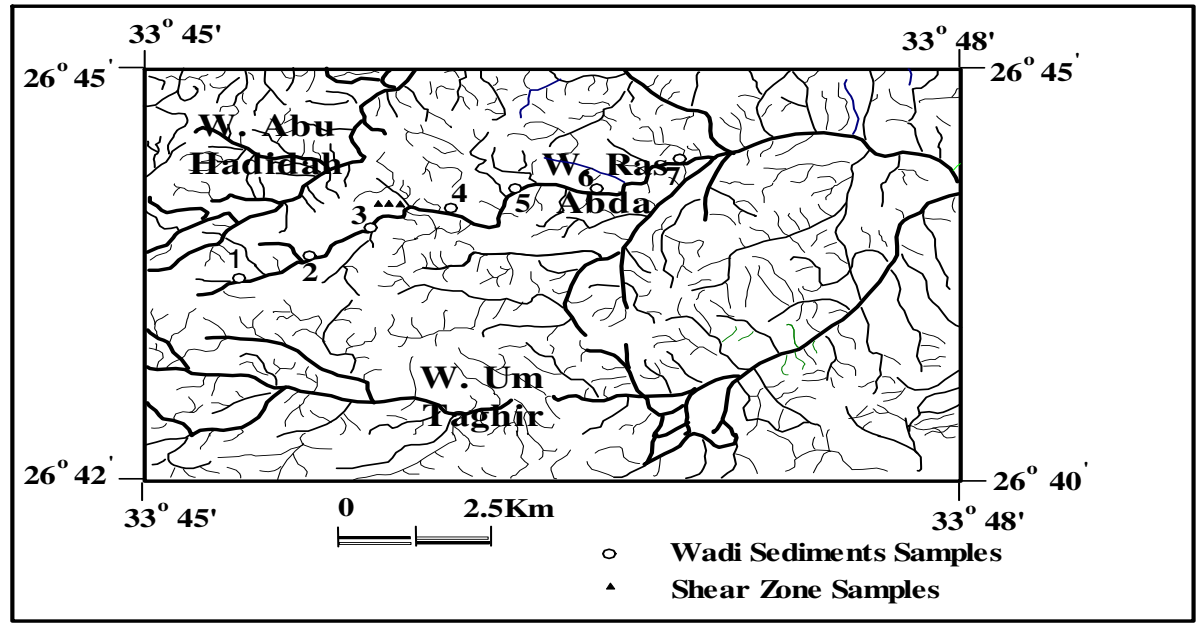

Fig.6: Drainage pattern and sample locations of the studied area. 
abundant in the southern parts, where there are sharp intersections between the main stream and its tributaries. This indicates the direct fractures control (fault or joints).

\section{PETROGRAPHY}

The exposed igneous rocks in the studied area comprise granitic rocks and younger gabbro.

The studied granitic rocks comprise older granitoids and younger granites. The nomenclature of granitic rocks is mainly related to the mineral composition especially quartz, feldspars, ferromagnesian minerals and accessories (Cox et al., 1979). Representative thin sections of granitic rocks were petrographically studied in details to identify the different mineralogical variations. Fifteen thin sections were selected for modal analyses $(9$ for older granitoids and 6 for younger granites). The results are summarized in table 1 and plotted in QAP diagram of Streckeisen 1976 (Fig.7).

\section{The Older Granitoids}

They show a considerable variation in mineralogical composition and plotted in quartz diorites, tonalites and granodiorites fields. They are generally medium- to coarsegrained rocks with hypidiomorphic granular texture and composed essentially of various

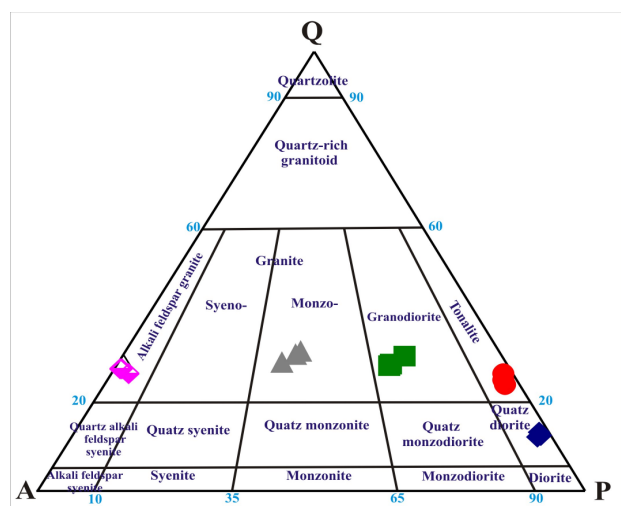

Fig.7: Modal composition for the studied granites (after Streckeisen, 1976) ratios of plagioclase, quartz, potash feldspars, hornblende and biotite.

The Quartz diorite:It is grey in color and essentially composed of plagioclase, hornblende and biotite together with little of quartz. Orthoclase is sometimes occurs as an additional mineral phase. Diopside, sphene, apatite and opaques are accessories, whereas epidote, saussurite and kaolinite are secondary minerals.

The Tonalite : It differs from the associated quartz diorites in being lighter in color (light grey to whitish-grey), richer in quartz content and contain less hornblende and more $\mathrm{k}$-feldspars and biotite.

The Granodiorite : It is pinkish grey to light grey in color and essentially composed of plagioclase, quartz, potash feldspars (perthites and microcline) and biotite with subordinate amount of hornblende. Iron oxides, apatite, zircon and sphene are accessory minerals, whereas chlorite, epidote, muscovite and calcite are the secondary minerals (Fig. 8). Granodiorite and tonalite are mutually rocks arbitrarily distinguished by the content of alkali feldspars $(<10 \%$ of total feldspar in tonalite). Moreover granodiorites resemble tonalites except for significantly higher alkali feldspars and somewhat higher quartz in the mode.

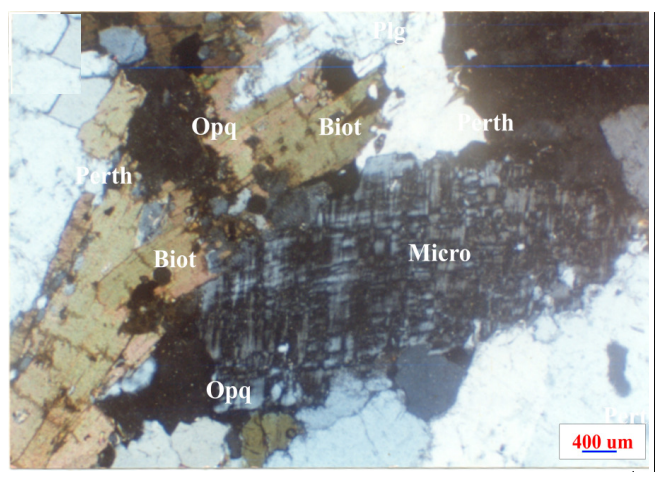

Fig.8: Altered plagioclase (Plg), microcline crystal with tartan-structure (Micro), quartz and biotite (Biot). The biotite is deformed, disturbed and engulfs opaques, Granodiorite,XPL, 


\section{The Younger Granites}

They could be classified petrographically into biotite-hornblende-granite, and alkali amphibole-granite. The biotite hornblende granite plotted in the monzogranites field, while the alkali amphibole-granite plotted within the alkaline granite field (Fig. 7).

The Monzogranite (biotite-hornblendegranite): It is medium to coarse grained, holocrystalline, showing hypidiomrphic granular texture and essentially composed of orthoclase perthite, quartz, plagioclase, hornblende and appreciable amount of biotite. Opaques, zircon, sphene and apatite represent the main accessory minerals whereas chlorite, sericite, kaolinite are the main alteration products (Fig. 9).

The Alkaline granite (alkali amphibolegranite): It is medium grained holocrystalline rock with hypidiomorphic granular texture. It is composed essentially of alkali feldspar (more orthoclase perthite and less sanidine), quartz, riebeckite, arfvedsonite, biotite and very little amounts of eigerine augite and albite. Zircon, apatite, curite, uranophane and opaques are accessory minerals whereas chlorite, sericite and kaolinite are secondary minerals (Fig. 10).

\section{The younger Gabbro}

The younger gabbro is hard and compact, fine to medium-grained black

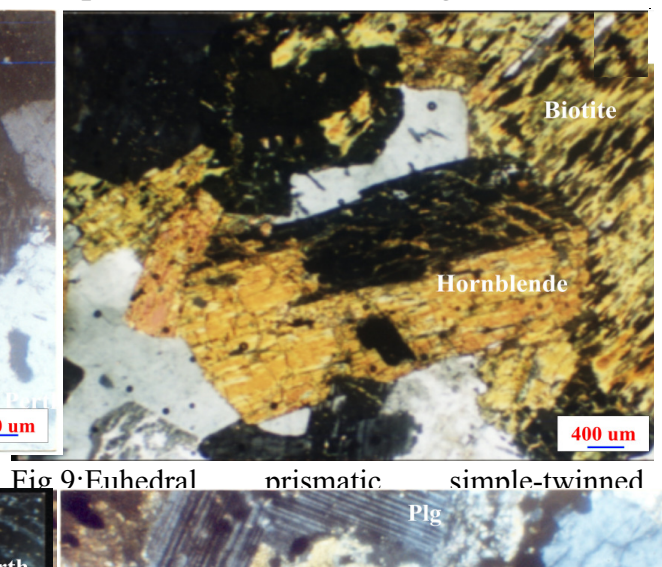

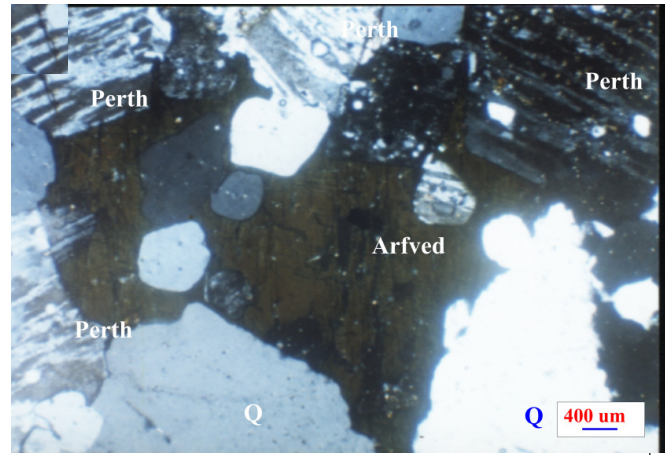

Fig.10: Arvedzonite crystal (arfved) poikilitically engulfs quartz and antiperthite and corroded with quartz $(Q)$ and patchy antiperthite (Perth). (A.G), XPL

colored rock. The rock is pyroxene-olivenegabbro with hypidiomorphic equigranular texture and essentially composed of plagioclase, clinopyroxene, hornblende olivine and opaques (Fig. 11). They are adcumulate rocks in which unzoned plagioclase crystals exhibiting adcumulus texture and entrap between them intercumulus mafic minerals.

\section{MINERALOGY}

Several samples are collected covering shear zone, and stream sediments deposits for mineralogical study.

Three samples were taken from shear zone. These samples crushed to different size ranging from $1 \mathrm{~mm}$ to $0.63 \mathrm{~mm}$, washed by $\mathrm{H}_{2} \mathrm{O}_{2}$, and $\mathrm{HCl}$, then drayed. A representative sample of about $60 \mathrm{gm}$ from each sample was separated by heavy liquid bromoform $2.88 \mathrm{gr} /$ $\mathrm{cm}^{3}$ and study under binocular microscope.

The stream sediments are represented by seven samples taken from wadi Ras Abda, in the most favorable points for accumulation of heavy minerals such as sharp bends of tributaries and the abrupt changes in the floor of the wadi, where the greatest orientation of heavy and valuable minerals can be expected. The distance between samples about $1.5 \mathrm{~km}$ start from up stream (south West) and ended to down stream (Fig. 6). These samples were 


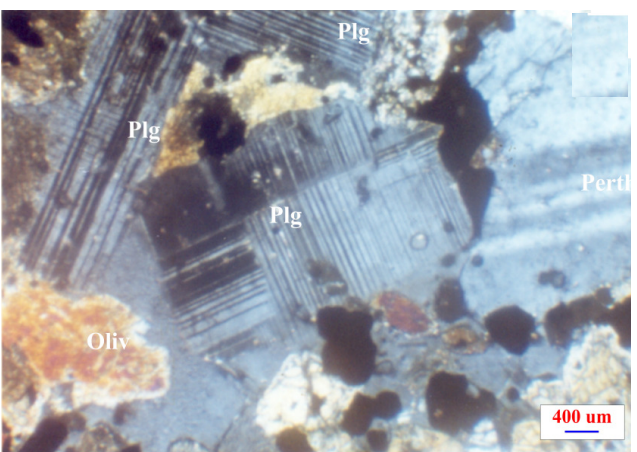

Fig.11: Plagioclase with albite and precline twining (Plg), olivine (Oliv) and opaques. pyroxene olivene gabbro,XPL

collected from open pits having about $50 \mathrm{~cm}$ diameter and about 50 to $80 \mathrm{~cm}$ depth. The average weight of each sample is about $10 \mathrm{~kg}$. A representative sample of about $60 \mathrm{gm}$ from each sample was separated by heavy liquid bromoform $2.88 \mathrm{gr} / \mathrm{cm}^{3}$ and study under binocular microscope.

Mineralogical investigation of the mineral constituents of the samples was carried out by using binocular stereomicroscope, $\mathrm{X}$ ray diffraction technique. Semi quantitative EDX chemical analyses were also carried out using a Phillips XL-30 Environmental Scanning Electron Microscope (ESEM). All these analysis were carried out in the laboratories of the Nuclear Materials Authority (NMA), Egypt.

The mineralogical investigations revealed the presence of several important heavy minerals. These minerals include magnetite, hematite, ilminite, garnet, zircon, sphene (titanite), columbite, curite, samarskite, chromite and platinum.

\section{Magnetite $\left(\mathrm{Fe}_{3} \mathrm{O}_{4}\right)$}

It represents the major part of opaque grains of the studied samples. It is black granular masses, and strongly magnetic, sometimes with zircon or garnet inclusions. It was separated by using small hand-magnet and thus subjected to EDX analysis. Magnetite is widespread in shear zone and Wadi sediments.
The Semi quantitative analyses (EDX) show high iron content with absence of $\mathrm{TiO}_{2}$, $\mathrm{Cr}_{2} \mathrm{O}_{3}$, (Fig. 12). The low content of chromium, titanium and vanadium suggests the granites origin (Lyakhovich and Lyakhovich, 1983).

\section{Ilminite $\left(\mathrm{FeTiO}_{3}\right)$}

Ilminite grains appear as granular aggregates, mostly black in color with blue or violet tint, sometimes as composite grains with parts of Samarskite (Fig.13), It is detected by using XRD and EDX techniques. It represents the most predominant opaque grains in the studied samples.

\section{Garnet (Iron aluminum silicate) $\left\{\mathrm{Fe}_{3} \mathrm{Al}_{2}\left(\mathrm{SiO}_{4}\right)_{3}\right\}$}

Garnet presents in the area near shear zone as grossular and almanden garnet, Almandine is well crystallized grains while grossular type appears as deformed grains with platinum inclusion. Its color varies with its chemical composition and ranges from pale pink, honey to deep honey, yellowish and colorless grains with vitreous luster. The presence of this min-

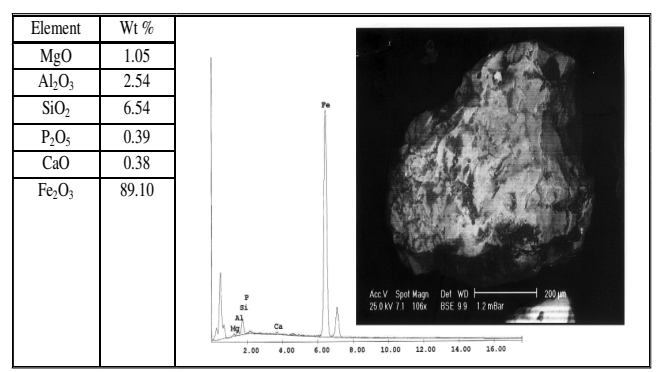

Fig.12:: EDX and BSE of Magnetite grain.

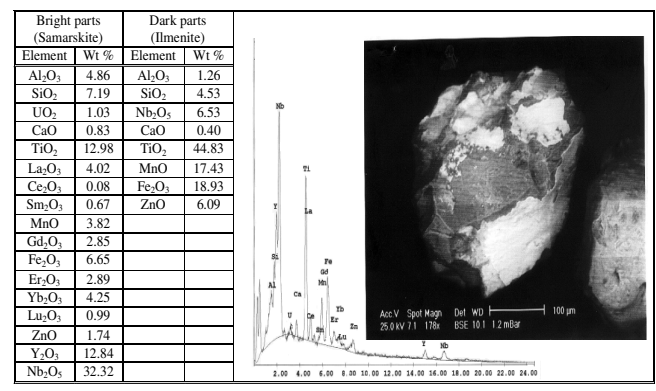

Fig.13: EDX and BSE of composite grain of ilmenite and samarskite. 
eral is an indication to metamorphism process. The EDX images of some garnet grains revealed the presence of almandine-spessartine solid solution garnet (Fig.14).

\section{Zircon ( $\left.\mathrm{ZrSiO}_{4}\right)$}

Zirconium tends to be concentrated in the late stage of silicic magmas stage, where it becomes capable to form minerals of its own, particularly zircon as in the shear zone in Wadi Ras Abda area. Zircon usually contains U concentration ranging from $0.01 \%$ to $0.19 \%$ and Th concentration ranging from $1 \%$ to $2 \%(\mathrm{Cu}-$ ney et al., 1987). Two types of zircon are present; the first one is small prismatic, colorless, yellow and purple with inclusions and the second type is large highly metamicted crystals with many fractures, which filled by uranothorite and silica. The first type is predominant in all of wadi sediment samples, while the second type is restricted to samples taken from shear zone and the area near it. It revealed that, the area may be affected by hydrothermal solution enrichment of uranium, during the tectonic activity in the area.

The presence of zircon in the studied samples was confirmed either by microscopic investigation and ESEM. ESEM data indicate that zircon consists mainly of $\mathrm{ZrO}_{2}$ and $\mathrm{SiO}_{2}$ with trace amounts of $\mathrm{Ca}$, Hf. $\mathrm{Fe}$ and $\mathrm{Al}, \mathrm{U}^{2}$ and Th (Fig.15).

The average of $(\mathrm{Zr} / \mathrm{Hf})$ ratios in zircon from sedimentary and meta-sedimentary rocks on one hand and in granitods on the other are extremely similar at 36.3 and 37.3 correspond-

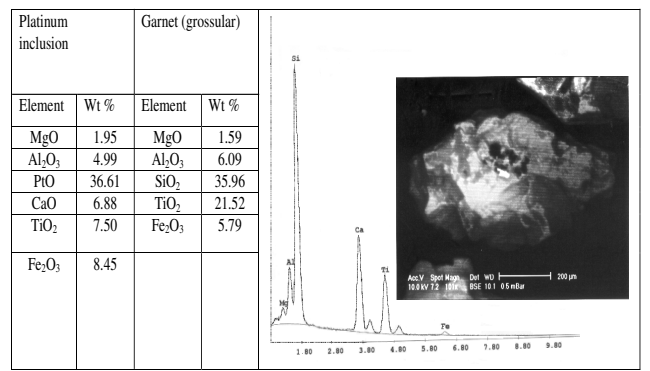

Fig.14: EDX and BSE of composite grain of Garnet.

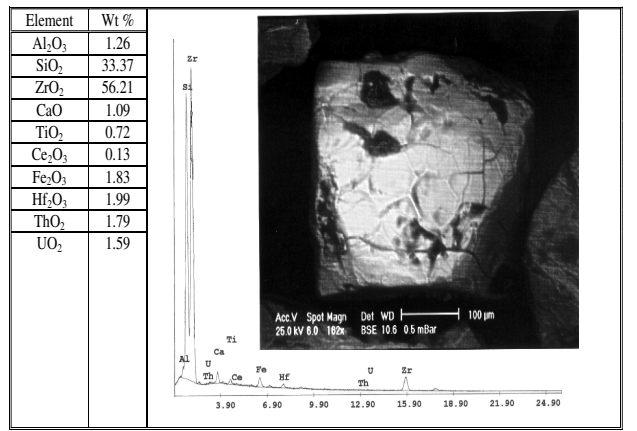

Fig.15: EDX and BSE of deformed Zircon grain.

ingly, while the least Hf content occurs in ultrabasic rocks, for instance, $\mathrm{Zr} / \mathrm{Hf}=$ up 49.6 in volcanic rocks, and from 55.7 to 76 in basic and ultrabasic rocks (Lyakhvich \& Vishnevskiy 1990). The $\mathrm{Zr} / \mathrm{Hf}$ value is about 28.25 to indicate acidic origin.

\section{Sphene (Titanite) Ca Ti Si $\mathbf{O}_{5}$}

Sphene is more common in stream sediments as well as the shear zone rocks of the studied area. It has color varies from brown to brownish yellow with vitreous luster. It appears as euhedral, prismatic wedge-shaped. The EDX image of sphene indicated that sphene grains exhibit striations (Fig.16). It is mainly derived from granitic rocks.

\section{Columbite $\left\{(\mathrm{Fe}, \mathrm{Mn})(\mathrm{Nb}, \mathrm{Ta})_{2} \mathrm{O}_{6}\right\}$}

Columbite is mainly derived from shear zone, and wadi sediment samples of the middle and down stream area. It appears as prismatic, tabular or platy crystals, often in heartshaped twins, striated, black with metallic appearance. Epitaxial overgrowths of columbite and samarskite occur. It detected using EDX technique (Fig.17).

\section{Samarskite (Oxides and Hydroxides) \{ (Y,Ce,U,Ca,Pb) (Nb,Ta,Sn) $\left.{ }_{2} \mathrm{O}_{6}\right\}$}

It is present as accessory of many granitic pegmatites rich in rare earth elements and niobium. The crystals are rectangular prisms, striated, velvety-black with brown surface alteration. Also it is present as fracture filling in deformed zircon crystal. Samarskite is present 


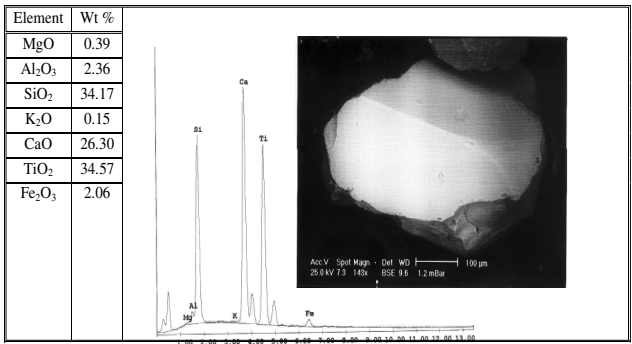

Fig.16: EDX and BSE of sphene grain.

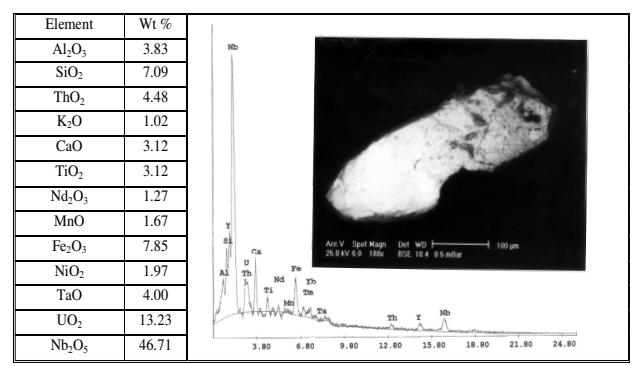

Fig.17: EDX and BSE of composite grain of Columbite

in shear zone and down stream samples. It is detected using EDX technique (Fig.18).

\section{Chromite $\mathrm{FeCr}_{2} \mathrm{O}_{4}$}

It is small, black to brownish black color, submetalic luster, granular masses (Fig.19). It is drifted from ultramafics. The chromite is derived from younger gabbro in the northern part of the area through small tributaries.

\section{Platinum (Pt)}

The natural platinum forms complicated mixed crystals and other intermetallic alloys with $\mathrm{Fe}, \mathrm{Ir}, \mathrm{Cu}, \mathrm{Pd}, \mathrm{Rh}, \mathrm{Ru}$, etc. It is always with $\mathrm{Fe}$ (up to $20 \%$ ), minor $\mathrm{Ir}, \mathrm{Cu}, \mathrm{Pd}, \mathrm{Rh}$, $\mathrm{Ru}$, with the result that it is not possible to determine which of the accessory elements are present in solid solution, and which as inclusions or gross impurities. Platinum-group mineralization (PGM) is formed from sulfide liquid in the chromitites; or it is crystallized directly from the silicate magma. Possibly the sulfide liquid that was trapped between the chromite grains lost some $\mathrm{Fe}$ and $\mathrm{S}$ by reaction with the chromite and this proved the

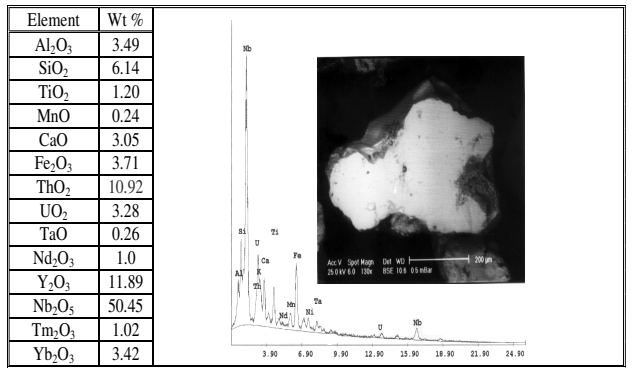

Fig.18: EDX and BSE of samarskite grain

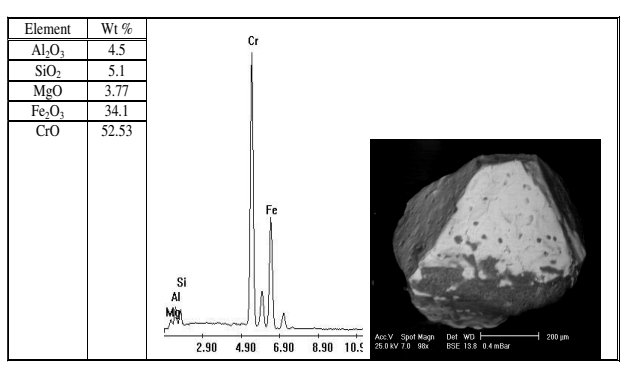

Fig.19: EDX and BSE of composite grain of chromite

crystallization of (PGM) from the sulphide liquid (Barnes and Maier; 2002).

Recently it has been shown that platinum can be transported under pneumatolytic-pegmatitic and even under hydrothermal conditions, especially the latter one was recently emphasized ( Ramdohr, 1980). Platinumgroup mineralization has recently reported in podiform chromites from the late proterozoic Pan-Africaan ophiolite of the Eastern Deasert of Egypt.

Ras Abda samples collected in or near drainage channels reflect Pt concentrations in the catchments area. It presents as Pt alloys with $\mathrm{Fe}$, or as fracture filling in deformed garnet grains (Figs. 14\&20).

The younger Gabbro in the area is mafic rock rich with $\mathrm{Cr}, \mathrm{Co}, \mathrm{Ni}, \mathrm{Cu}$, and $\mathrm{Pt}$. When the area was affected by some faults associated with hydrothermal solution, it becomes rich with $\mathrm{Fe}, \mathrm{Mn}, \mathrm{Cu}, \mathrm{Zn}, \mathrm{Cr}, \mathrm{Ni}, \mathrm{Co}$, and Pt. The weathering products of younger gabbros transported make the wadi deposits reaching 


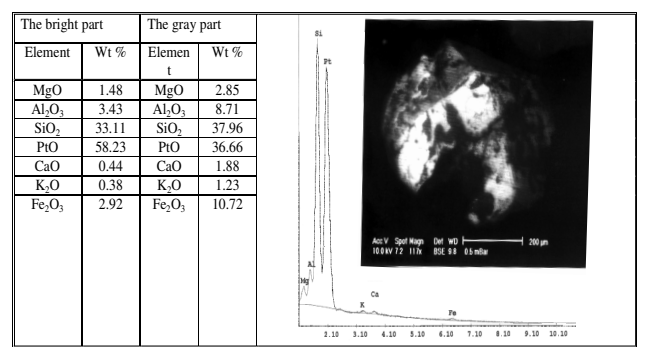

Fig.20: EDX and BSE of composite grain of Platinum

with the weathering product of younger gabbros as $\mathrm{Cu}, \mathrm{S}, \mathrm{Cr}$, and Pt.

\section{CONCLUSION}

The area is limited by longitude $33^{\circ} 45^{\circ}$ and $33^{\circ} 48^{\circ} \mathrm{E}$ and latitude $26^{\circ} 42^{\circ}$ and $26^{\circ} 48^{\circ} \mathrm{N}$ in the central Eastern desert. It is crossed by several wadis as wadi Ras Abda and wadi abu hadidah.

The exposed rock types in the area comprise the older granitoids, younger gabbros and younger granites as well as several types of post granite dikes. Wadi Ras Abda has length of about $10 \mathrm{~km}$ and width reaches to 50 $\mathrm{m}$, mainly surrounded by the older granitoids. These granitoids are characterized by the presence of small pockets of mineralized pegmatite and several lenses of mineralization. The shear zone reaches about $40 \mathrm{~m}$ in length and $10 \mathrm{~m}$ in width.

The area is affected by two right-lateral strike-slip faults trending NE-SW and NWSE. The NW right-lateral-slip faults of parallel and conjugated dip direction due NE and SW form a big graben. It extends $10.4 \mathrm{~km}$ to $\mathrm{NW}$ $\mathrm{SE}$ and $3.2 \mathrm{~km}$ width.

The drainage patterns of the studied area are generally dendritic and angular. The dendritic type is restricted in the northern part where fractures, joints, and faults occur. The angular pattern type is abundant in the southern parts, where the sharp intersection between the main stream and its tributaries. This is indicates that the area was structurally controlled.
The important determined heavy minerals are represented by magnetite, hematite, ilminite, sphene, zircon chlorite, chromite and platinum. Radioactive minerals as curite, samarskite, columbite (nubium-tantalite) and uranophane are also present. Several anomalous mineralized zones and spots confined to shear zone related to the faults affecting the area. These faults may be provided the possible pathways for hydrothermal solutions enriched in uranium and trace elements, during the tectonic activity of the area. Prtrographical and mineralogical studies revealed the presence of radioactive minerals such as curite, uranophane and samarskite as well as minerals rich in radioactive elements as zircon and Columbite in the acidic rocks of the area especially along the shear zone. This phenomenon indicates that, the acidic rocks may be originated from magma rich in radioactive elements. On the other hand, the effects of such complicated structures in the area increases of the presence potential of radioactive minerals. Therefore, the researchers recommended to conduct detailed studies in this area in the near future.

\section{REFERENCES}

Akaad, M. K., and Moustafa , G. A., 1963. The shait granite, a cataclastic mylonitic granodiorite. Geol. Surv. Egypt, No. 18, 19p.

Barnes, S.J., and Maier, W.D.,2002. Platinumgroup elements and microstructures of normal Merensky Reef from Impala platinum mines, Bushveld complex. J. Petrol., 43 No. 1, 103128.

Carey, E., and Brunier, B.,1974. Analyse théorique et numérique d'un mod (le mécanique élémentaire appliqué à l'étude d'une population de failles. C. R. Acad. Sci. Paris, D 279, 891-894.

Cox, K. G.; Bell, J. D., and Pankhurst, R. J., 1979 The interpretation of igneous rocks. William Clowes, London, Britain, 414 p.

Crowell, J. C., 1974b. Origin of late Cenozoic basins in southern California. In: Tectonics and sedimentation (Dickinson, W. R., Ed.): Tulsa, 
Oklahoma, Soc. Econo. Sediment. Mineral., Special Publication 22, 190-204.

Cuney, M.; Le Fort, P., and Waneg, Z. X.,1987. Geology of granites and their metallogenetic relations, Science press, 853-873.

Egyptian Geological Survey and Minerals Authority (EGSMA),1987. Geological map of Basemen Rocks of Safaga Quadrangle, Egypt, on scale 1:100 000. Ministry of Petroleum and Mineral Resources.

El-Gaby, S.; List, F.K., and Tehrani, R.,1990. The basement complex of the Eastern Desert and Sinai. In: The geology of Egypt The geology of Egypt (Said, R.,Ed): Balkema-RotterdamBrookfield.

El-Manharawy, M. S., 1977. Geochronological investigation of some basement rocks in central Eastern Desert, Egypt between lats. $25^{\circ}$ and $26^{\circ}$ N., Ph.D. Thesis, Cairo Univ., Egypt.

El Ramly, M. F.,1972. Anew geologic map for the basement rocks in the Eastern Desert and Southwestern desert of Egypt . Ann. Geol . Surv., Egypt., II , 1-18.

El-Shazly, E. M.,1964. On the classification of the precambrian and other rocks of magmatic affiliation in Egypt. Inter. Geol. Congr. Proc. Sect. 10, India, XX $11,88-101$.

Garfunkel, Z., 1981. Internal structure of the Dead Sea leaky transform (rift) in relation to plate kinematics. Tectonophysics, 80,81-108.

Hashad, A. H., 1980. Present status of geochemical data on the Egyptian basement complex. Inst. App. Geol. Bull. (Leddah), 3, 31-46.

Hussein, A. A.; Ali, M. M., and El-Ramly, M. F., 1982. A proposed new classification of the granites of Egypt. J. Volc. Geoth. Res., 14, 187198.

Lyakhovich, V.V., and Vishnevskiy, A.A.,1990. Zr and $\mathrm{Hf}$ in rapakivi zircons and theorigin of the ovoids. Geokhimiya, 8, $1075-1038$.

Lyakhovich, T.T. and Lyakhovich, V.V.,1983. New data on accessory mineral compositions. Geochem. Intr., No. 6, 20, 91-108.

Mann, P.; Hempton, M. R.; Bradley,D.C., and Burkr, K., 1983. Development of pull-span basin, J. Geol., 91, 529-554.

Noweir, A.M.; Sewifi, B.M. and Abu El-Ela, A.M., 1990. Geology, petrography, geochemistry and petrogenesis of the Egyptian Younger Granites. Sci. Bull., Qatar Univ., 10, 363-393.

Ramdohr,P.,1980. The Ore Minerals and their Intergrowths. $2^{\text {nd }}$ Edition (international series in earth sciences; 35 .

Rogers, J .J. W., and Greenberg, J. K., 1983. Summary of recent work on Egyptian younger granites. Ann. Geol. Surv. Egypt, 13, 185-191.

Schubert, C.,1984. Basin formation along the Bocono, Moron, El Pilar fault system. Venezuela J. Geophysical Research,89: doi:10.1029/JGREA 0000890000B7005711000001.issn:0148-0227.

Silvester, A. G.,1988. Strike-Slip faults. Geol. Soc. Amer. Bull., 100, 1666-1703.

Stern, R. J.,1979. Late Precambrian crustal environments as reconstructed from relict igneous minerals, Central Eastern Desert of Egypt. Ann. Geol. Surv. Egypt, IX, 9-31.

Stern, R. J., and Hedge, C. E.,1985. Geochronologic and isotopic constraints on late precambrian crustal evolution in the Central Eastern Desert of Egypt. Amer. J. Sci., 285, 97-127.

Stern, R. J.; Gotteried, D., and Hedge, C. E.,1984. Late Precambrian rifting and crustal evolution in the North Eastern Desert of Egypt. Geol., No. 12,168-172.

Streckeisen, A., 1976. To each plutonic rock its proper name. Earth Sci. Rev., 12, 1-33.

Şengör, A. M. C.; Görür, N., and Şaroğlu, F.,1985. Strike-slip faulting and related basin formation in zones of tectonic escape: Turkey as a case study; Strike-slip Deformation, Basin Formation, and Sedimentation. Soc. Econ. Paleont. Min. Spec. Pub. 37 (in honor of J.C. Crowell), 227-264. 


\section{مساهمة فى جيولوجية ومعدنية منطقة وادى راس عبدا ـشمال الصحراء الشرقية, مصر-}

$$
\text { أحمد فؤاد الحضرى ، أشرف العزب و على أحمد عمران }
$$

تقع منطقة و ادى رأس عبدا فى شمال الصحر اء الثرقية على بعد حولى · اكم من مدينة سفاجا الو اقعة على ساحل

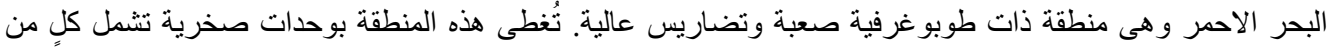

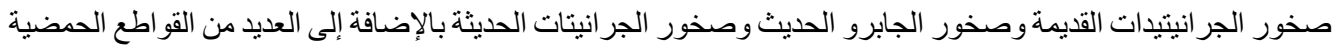

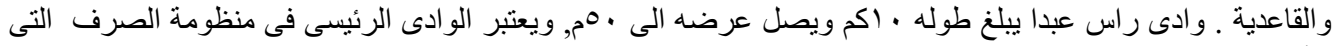

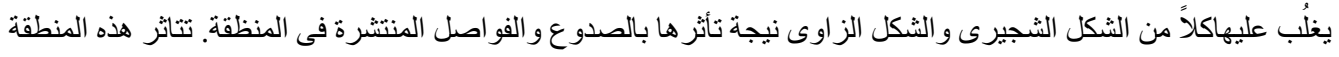

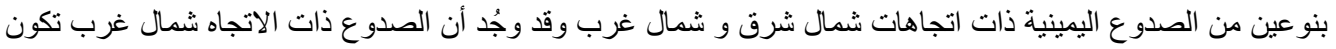

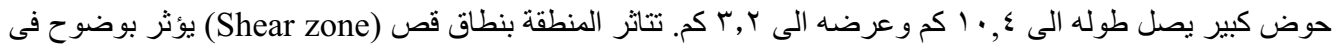

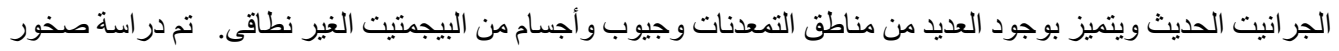

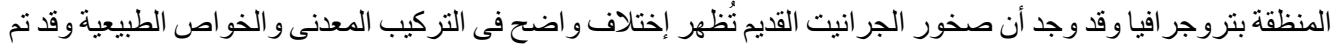

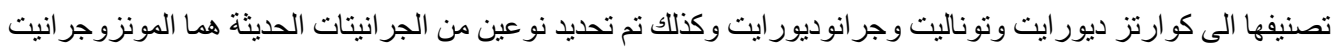

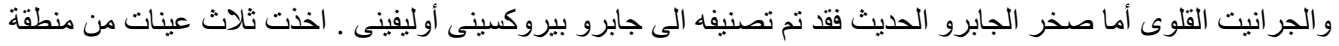

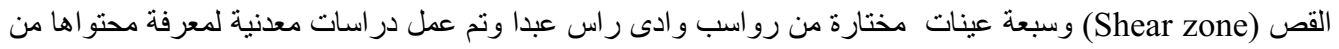

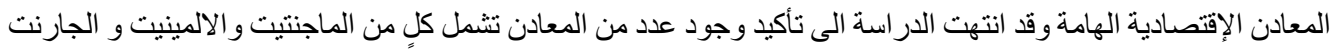

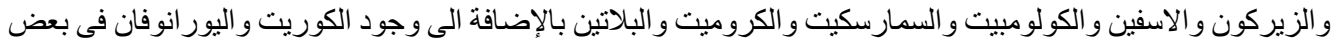

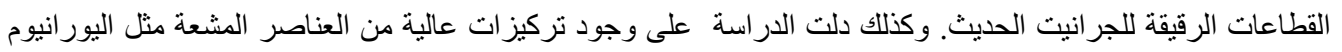

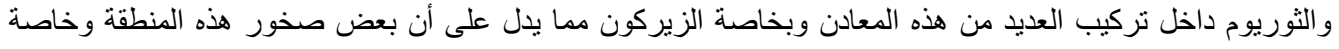

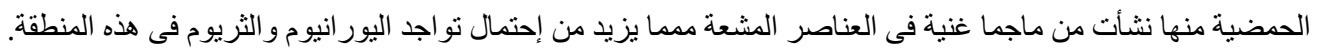

